I know these fossils are a common occurrence in limestone formations, but I feel very humble and somowhet stunned when I think that the whole of that 82 feet depth of earth, and who knows how much besides, has been dumned there in some prehistoric ase and perhaps brought here from hundreds of miles away. It must surely be a very wonderful story for whoever can rend the riddle."

"The pocket gopher is on the increase in the Wallwort district, probably due to the increased acrease seeded to alfalfa. Richardson's ground squirrel is also on the increase during our dry seasons."

$$
\text { J. Turnquist, Wallwort, Sesk, }
$$

\title{
MUSEUM NOTES
}

Museum Open House:

Fred G. Bard

On Dec. 15th the Regina Natural History Society, in place of its regular monthly mecting, will attend "open House" at the Provineial Museum, Normal School. Mr. J. Buckley the President will open with a few remarks to members and introduce the Hon. J.H. Sturdy, Minister of Reconstruction and Rehabilitation who will officially welcome the guests. The society has extended an invitation to the Archaeologicel Society to attend on this occasion.

The visitors will have an opportunity of viewing behind the scenes, talking with the staff members, discussine points of interest relative to the work. It is expected a better understanding will come about during this informal meeting.

\section{Museum Observers:}

Observers are welcome to send in notes relative to Natural History in Saskatchewan to the Provincial luseum, Regina.

Bradshaw, Euchanan, Furniss, Harold, Holmes, Mitchell, Perce, Potter, Symons, are șome whose names have added a grent deal to faunal records for Saskatchewan: These men are no longer with us, for the most part they have moved from the Province. The standard they have set is high; it will not be easy to replace such men, but through selection, fuidance and encouragement, time will a gain provide us with the coverage we need; therefort, anyone deeply interested, and with a fair knowledse of birds, animals etc., of Saskatchewan are invited to send their observations to the Museum. This information is netded to determine the abundance and distribution of species, and their chane from year to year.

Eagles, Hawks, Owls

Too often we read in the press, accounts of easles being shot and the proud hunter tells in detail all that leads up to the killing.

There is nothing very wonderful about killino in this day and age, with the use of smokeless powder and modern guns that will fire with great rapidity. I can understand the need for farmers, poultry raisers to toke matters into their own hands to deal with the offenders when the need arises, but there is no justification in each owner of a kun,killine everything he sees, 
This feeble attempt of the restoration of nature's balance is the deduction of ignorant people who refuse to be shown. Nothing was created without value, and to condemn species as a whole is unjust and wrong. By comparison, robins enjoy a position of difnity, suggest peace, love and beauty and yet few birds contribute as little as robins when we speak of economy and beneficial birds. Their habit of eating fruit makes the fruit growers' life a difficult one, and their habit of eating earth worms is decidedly not in the interests of soil conservation.

The resources of a nation is her wealth. Forests, lekes, rivers, soil, game and fur when depleted take generations to rebuild, some call never be rebuilt. These losses break down our economy, leaving it devoid of beauty. Are we to destroy everything within our reach, or will we. lealn to use these resources sensibly, before it is too late!

This wonderful herita $e$ is entrusted to our care, to hand on down to generations yet unborn. Our conduct and care of these resources effects the civilizations of the future, the issue rests with us.

\section{Coyotes}

Currently issues have been aired by the Sheep Ereeders? Association "We have to make up our minds if we are to raise coyotes or sheep" says the president of the Association.

When the mounted coyote in the luseum was being photographed to illustrate the sheep breeder'sistory, we expressed an opinion which speaks of its value. We understand and sympathize with the farmers who are losing poultry and sheen but we see no reason to condemn the snecies when the blame can only be attached to a few rogue or killer coyotes. The coyote fur in Saskatchewan last year totalled \$100,000.00 in value. This must be placed on its credit side. The coyote as a rodent controller cannot be minimized. The wholesale killing of rabbits has undoubtedly a bad effect on the coyotes eating habits. Unskinned carcasses of Jack llabbits have brought $\$ 1.00$ apiece. I know of two hunters who shot 38 Jack Rabbits in a sinsle night with the use of a spot light. Using spotlights to hunt is unsporting and illegal and practices of this kind only causes shortages in feeding habits, resulting in more trouble.

\section{Whooping Cranes:}

Observers are asked to submit records of misration dates, location etc., of Whooping Cranes. These records will be relayed to $\mathrm{R}$. P. (Bob) Allen, who is employed by the Audubon Society and at present in Texas working to save the Whooping Cranes from extinction.

It is with regret, to my knowledge the last four Whooping Cranes shot in Saskatchewan were, one by a teacher, and three by hunters. Two were confiscated and now in the Provincial Museum, the other two we have no record of, such facts written into the history of such a magnificent bird is more than regrettable, and points definitely to the need for education.

It is a recognized fact, but few sportsmen are able to identify the specimens they take. Flunase's, habits $s^{*}$ liff histories, etc., are fascinating to those who come to understand nature. They readily acknowledge how much more interesting are their trips to the field. With such knowledge they can work in harmony with nature's requirements during times of scarcity. 
Deer

The recent season on Deer for residents south of township 33, closed on November 22nd following eleven opendays. Winter conditions prevailed with several inches of snow on the ground and temperitures rengine from zero to 23 above on an averase.

Deer seemed to be fairly common about the valley. Relative proportions seemed to be $5-1$ in favor of white-teiled deer. Two hybrids were exarined and while strongly favoring white-tails, there were distinct, characteristics suggesting mule deer.

While returns are not conplete to date 1905 licenses were sold,1787 reported taking deer as follows: 1319 males, 468 females. Generally south of 33, is for the most part farmland. The deer hunting usually applied to coulee's and rolling bluff country.

It is a wonderful privilege to participate in the hunting of deer in settled areas. It is to be hoved hunters will respect the riohts of the farmer, and too, act in the best intereste of game to insure both a plentiful supply of game and to work in harmony with the land owners.

\section{Great Grey OwIs:}

Great Grey Owls were reported in winters of 1890 - 1916 - 1917 at Indian Head by Geo. Lang. Specimen taken in 1936 on the Assiniboine Feserve Sintaluta, by Jack Wilson, mounted and now in Indian Head.

First Museum spec. male taken winter of 1938 by F. D. Symons at Mtn. Cabin, Carrot River, taken from a steel trap starved and frozen to deeth.

Another specimen identified from feet sent in to Fish and Game League Owl campain of 1940 - 4l. winter. The feet were submitted by F. Vissler, Moosedale, Sask.

\section{Starlings:}

An incuiry comes in from John Stainer, Longmynd, Cherry Point, Cobble Hill, B. C. The information required is: the direction from which immigration sterted, dates and places of first stragolers, first nesting records, etc.

All information should be sent to Rejina. We will copy such material for our files and relay all information to Mr. Stainer.

Pacific Loon:

While hunting ducks southeast of Regina some 23 miles, near Kronau, Dr. C. Dixon of this city shot a Pacific Loon. The bird, an aduit female, is being prepared as our first Provincial record. From Mitchell's catrlosue of Saskatchewan birds, McFarlone collected a specimen and eggs of this loon c.t Lake Athabasca's west end in 1885. 


\section{Wildlife Pictures:}

On November 24 th at the Central Public Library, speaking to the Mrchaeolosical Society, Mr. Doug. Gilroy of Bredin Siding, presented personally taken colored stills of natural history. Mr. Gilroy's splendid pictures were unique in quality, depicting several interesting stories. Outstanding were his stories of the weasel in winter, nesting photos of the Saw-whet Owl. The pictures represented subjects on $\mathrm{Mr}$. Gilroy's farm, proving as often said how much there is to see, if we but look for nature's marvels.

\section{Reptiles and Amchibians}

We require all the information you may have of Reptiles and Amphibians, this information is requested by the Nanitoba Museum. All records must be sent to The Provincial Museum, Regina.

Past and present appearances are required on distribution, abundance and dates, such records noed not apnly to your district but they must be Saskatchewan records.

Information is needed of Salamanders, Mud Puppies, Toads, Frogs and Snakes. If you are well enough acquainted with differences in species, then please include available data.

We are in need of field records covering all branches of Natural History. Those seriously interested in nature will render a great service to the museum by actively taking part. At the museum such information is readily available to anyone. It should not be necessary to mention the historical significance of such records. 